\title{
Quality and Technological Properties of Gluten-Free Biscuits Made with Pachyrhizus ahipa Flour as a Novel Ingredient
}

\author{
María Cecilia Doportoํㅜ, Fernanda Sacco ${ }^{1}$, Sonia Z. Viñaa ${ }^{1,2}{ }^{*}$, María Alejandra García ${ }^{1}$ \\ ${ }^{1}$ Centro de Investigación y Desarrollo en Criotecnología de Alimentos (CIDCA), Facultad Ciencias Exactas, Universidad Nacional de \\ La Plata (UNLP)-CIC-PBA-CONICET La Plata, La Plata, Argentina \\ ${ }^{2}$ Curso Bioquímica y Fitoquímica, Facultad Ciencias Agrarias y Forestales (UNLP), La Plata, Argentina \\ Email: *soniavia@quimica.unlp.edu.ar
}

How to cite this paper: Doporto, M.C., Sacco, F., Viña, S.Z. and García, M.A. (2017) Quality and Technological Properties of Gluten-Free Biscuits Made with Pachyrhizus ahipa Flour as a Novel Ingredient. Food and Nutrition Sciences, 8, 70-83. http://dx.doi.org/10.4236/fns.2017.81005

Received: November 14, 2016

Accepted: January 7, 2017

Published: January 10, 2017

Copyright $\odot 2017$ by authors and Scientific Research Publishing Inc. This work is licensed under the Creative Commons Attribution International License (CC BY 4.0).

http://creativecommons.org/licenses/by/4.0/

(c) (i) Open Access

\begin{abstract}
The development of gluten-free foodstuffs with high nutritional quality components is an important objective to achieve. Pachyrhizus ahipa is one of the few leguminous species that produce edible tuberous roots with high nutritional value. Thus, the aim of this work was to formulate biscuits containing corn starch and $125-350 \mathrm{~g} \cdot \mathrm{kg}^{-1}$ of P. ahipa flour (AF) and to study the main physicochemical properties related to their nutritional and technological quality as well as their sensory acceptability. The formulation containing $250 \mathrm{~g}$ of $\mathrm{AF} \mathrm{kg}^{-1}$ was selected for improving the product nutritional quality (i.e. higher protein content) without an extensive modification of textural properties. A formulation replacing corn starch by cassava flour $\left(250 \mathrm{~g} \cdot \mathrm{kg}^{-1}\right)$ was also analyzed. In this case, ahipa and cassava biscuits showed maximum force and energy required to bite twice and three times higher than the control, respectively. Slight variations were observed in color ( $\Delta \mathrm{E}$ and browning index). The overall acceptability of biscuits formulated with both flours was better scored than the control by a sensory panel. Principal component analysis allowed to relate quality attributes, chemical composition, and sensory characteristics of biscuits containing cassava or ahipa flours. The results indicated that ahipa flour could satisfactorily substitute part of the corn starch used in the formulations of gluten-free biscuits.
\end{abstract}

\section{Keywords}

Non-Traditional Flours, Biscuits for Celiac Patients, Chemical Composition, Color and Texture, Sensory Evaluation

\section{Introduction}

In quantitative terms, the gluten-free food market has shown a big grow in the last 
years, evidencing an annual rate of $28 \%$ [1]. For instance, the US gluten-free food and beverage sales are expected to surpass $\$ 6.6$ billion by 2017 [2]. Nevertheless, most of the time nutritional status and demands of celiac patients are not satisfactorily covered when formulation and production of gluten-free products is carried out [3].

People on a strict gluten-free diet are frequently undernourished since their rapidly available-energy intake, which in the western diet is largely taken from wheat-based foodstuffs, is reduced. This circumstance has prompted the development of gluten-free foodstuffs with high nutritional quality components [4] [5]. In general, gluten-free baked goods comprises several raw materials like rice, corn, buckwheat, cassava, and potato starches and/or flours [6]. At present, crops like amaranth, teff, and quinoa, which are comparatively novel or lesser known on the gluten-free market, are offered. Thus, the variety of gluten-free products is expanding every year [7].

On the other hand, in many tropical areas where wheat does not grow well, attempts are made to encourage the use of flours from locally grown crops which could totally or partially replace wheat flour for use in baked goods. This fact would contribute to decrease the demand for imported wheat and to obtain protein enriched products [8].

Pachyrhizus is one of the few genera of the leguminous family that produce edible tuberous roots with high nutritional value [9]. The species $P$. ahipa (Wedd.) Parodi produces thickened roots that accumulate low-amylose starch. Likewise, the protein content of $P$. ahipa roots has also motivated scientific and technological interest in this product [10] [11]. From a nutritional point of view, $P$. ahipa flour showed a more balanced chemical composition than other root and tuber ( $\&$ \& ) flours. It might contribute protein, fiber, and minerals, such as potassium, calcium and iron to the diet. Ahipa flour can be simply obtained by a slicing procedure bringing a product with higher content of potassium, magnesium, calcium and protein together with a higher water-holding capacity than the flour obtained by grating plus pressing [11]. Ahipa flour showed an acceptable stability when kept at $10^{\circ} \mathrm{C}, 20^{\circ} \mathrm{C}$ or $30^{\circ} \mathrm{C}$ at variable relative humidity, information obtained from the sorption isotherms analysis [12].

The objective of the present work was to formulate and elaborate biscuits containing Pachyrhizus ahipa flour and to study the main physicochemical properties related to their nutritional and technological quality as well as their sensory acceptability.

\section{Materials and Methods}

\subsection{Ingredients and Formulations}

Ahipa flour was obtained by a slicing procedure [11] [13]. Commercial corn starch was utilized as the main ingredient of the biscuits. Four biscuit formulations were assayed: a) control, with $1000 \mathrm{~g} \cdot \mathrm{kg}^{-1}$ corn starch (C); b) $125 \mathrm{~g} \cdot \mathrm{kg}^{-1}$ ahipa flour $+875 \mathrm{~g} \cdot \mathrm{kg}^{-1}$ corn starch (125AF); c) $250 \mathrm{~g} \cdot \mathrm{kg}^{-1}$ ahipa flour $+750 \mathrm{~g} \cdot \mathrm{kg}^{-1}$ corn starch (250AF); and d) 350 $\mathrm{g} \cdot \mathrm{kg}^{-1}$ ahipa flour $+650 \mathrm{~g} \cdot \mathrm{kg}^{-1}$ corn starch $(350 \mathrm{AF}$ ). For $300 \mathrm{~g}$ of corn starch (or the respective substitution mix), the remaining ingredients were eggs (one whole medium egg, approximately $58 \mathrm{~g}$, and a yolk), refined sugar (87.5 g; type "A" common sugar), butter (100 g; total fat $820 \mathrm{~g} \cdot \mathrm{kg}^{-1}$, saturated fat $510 \mathrm{~g} \cdot \mathrm{kg}^{-1}$, sodium $1400 \mathrm{mg} \cdot \mathrm{kg}^{-1}$, according to the supplier) and chemical leavening powder ( $2 \mathrm{~g}$ sodium bicarbonate $+2 \mathrm{~g}$ potassium hydrogen tartrate). 


\subsection{Cooking Conditions and Biscuit Analysis}

Biscuits were cooked in an electrical static oven (Ariston FM87-FC, Italy) under natural convection. Different baking conditions were assayed: $180^{\circ} \mathrm{C}-10 \mathrm{~min} ; 200^{\circ} \mathrm{C}-7.5 \mathrm{~min}$; and $200^{\circ} \mathrm{C}-10 \mathrm{~min}$. The main quality attributes (water activity, color, and texture) were analyzed, evaluating the biscuit characteristics for selecting the appropriate baking condition. Once the percentage of substitution of ahipa flour was selected, the formulated product was compared to the control and with a formulation made with the same proportion of cassava flour, which was chosen as a reference ingredient frequently incorporated in gluten-free product formulations.

\subsubsection{Water Activity $\left(\mathrm{a}_{\mathrm{w}}\right)$}

Water activity of the samples was measured at $25^{\circ} \mathrm{C}$ with a Water Activity Meter Aqualab series 3 (Decagon Devices Inc., Washington, USA). A solution of saturated $\mathrm{K}_{2} \mathrm{SO}_{4}$ was used as a calibration standard $\left(\mathrm{a}_{\mathrm{w}}\right.$ at $\left.25^{\circ} \mathrm{C}: 0.972\right)$. The average of three determinations, performed in two independent experimental batches, was informed.

\subsubsection{Texture}

Penetration tests were performed with a TAXT2i Texture Analyzer (Stable Micro Systems Ltd., Godalming, Surrey, UK). A $25 \mathrm{~kg}$ load cell was employed. The "Volodkevich Bite Jaws" probe was used in order to simulate the bite action of the incisive teeth on the sample. Parameters recorded were the maximum force $(\mathrm{N})$ exerted when compressing $20 \%$ the sample, which is related to product firmness, and the area under the force curve $(\mathrm{N} \mathrm{mm})$ that is directly associated with the energy required in the process [14]. Likewise, the number of peaks (variations in force higher than $0.02 \mathrm{~N}$ ) taken as an index of crunchiness were counted. The average of twelve determinations, performed in two independent experimental batches, was informed.

\subsubsection{Color}

Surface color was measured using a Chroma Meter CR 400 (Konica Minolta Sensing Inc., Japan) calibrated with a standard white plate $(\mathrm{Y}=93.2, \mathrm{x}=0.3133, \mathrm{y}=0.3192)$. Lightness $\left(\mathrm{L}^{*}\right)$, red-green coordinate $\left(\mathrm{a}^{\star}\right.$ value), and blue-yellow coordinate $\left(\mathrm{b}^{\star}\right)$ were registered. Color measurements were expressed as the total color difference $(\Delta \mathrm{E}) \mathrm{calcu}$ lated with respect to the coordinates $\left(\mathrm{a}_{0}{ }^{*}, \mathrm{~b}_{0}{ }^{*} \mathrm{y} \mathrm{L}_{0}{ }^{*}\right)$ that characterized the color of the control baked cookies (C) (Equation (1)):

$$
\Delta E=\sqrt{\left(\left(a^{*}-a_{0}^{*}\right)^{2}+\left(b^{*}-b_{0}^{*}\right)^{2}+\left(L^{*}-L_{0}^{*}\right)^{2}\right)}
$$

Likewise, the browning index (BI) [15] was calculated using the following equations:

$$
\begin{gathered}
x=\frac{a^{*}+1.75 L^{*}}{5.645 L^{*}+a^{*}-3.012 b^{*}} \\
B I=\frac{100(x-0.31)}{0.172}
\end{gathered}
$$

The average of twelve determinations, performed in two independent experimental batches, was informed. 


\subsubsection{Chemical Composition}

Total ash quantification $\left(\mathrm{g} \cdot \mathrm{kg}^{-1}\right)$ from dried samples $(6 \mathrm{~g})$ was performed gravimetrically after incineration in a muffle furnace (Indef 331, Córdoba, Argentina) at $550^{\circ} \mathrm{C}$. The liposoluble fraction ( $\mathrm{g} \cdot \mathrm{kg}^{-1}$ on a dry basis) was extracted with hexane from samples of grinded biscuits $(12 \mathrm{~g})$ in a Soxhlet apparatus. Likewise, baked biscuits ( $0.8 \mathrm{~g})$ were analyzed for total nitrogen content by the Kjeldahl method [16] and the results were expressed as crude protein ( $\mathrm{g} \cdot \mathrm{kg}^{-1}$ on a dry basis). The content of total dietary fiber (TDF, $\mathrm{g}^{\mathrm{kg}} \mathrm{g}^{-1}$ on a dry basis) was measured by the enzymatic kit K-TDFR 05/12 Megazyme $^{\oplus}$ (Ireland) from samples $(1.0000 \mathrm{~g})$ of grinded biscuits, previously defatted with hexane by the Soxhlet method, until completing eight cycles of extraction. Chemical analyses were carried out at least by duplicate, in two independent experimental batches.

\subsubsection{Sensory Evaluation}

A first sensory analysis was carried out using a semi-structured hedonic scale to evaluate the acceptability of the biscuits made with the selected percentage of substitution, cooked at different baking conditions $\left(200^{\circ} \mathrm{C}-7.5 \mathrm{~min}\right.$ or $\left.200^{\circ} \mathrm{C}-10 \mathrm{~min}\right)$. A total of 60 potential consumers evaluated biscuit color, texture, taste and overall acceptability according to a box-scale (1 - 9) anchored in the following steps: "dislike very much", "indifferent" and "like very much". Samples were presented to the evaluators randomly arranged and coded with three digit numbers.

Once the baking time was selected, a second sensory analysis was carried out where the panelists were asked to evaluate color, texture, taste, and overall acceptability of control and the selected ahipa or cassava flour biscuit formulations.

\subsection{Statistical Analysis}

The InfoStat Software (Version 2008) (InfoStat Group, Agricultural Sciences College, National University of Cordoba, Argentina) was used. Analysis of variance (ANOVA) and comparison of means with the Fisher's least significant difference (LSD) test were conducted, at a significance level $p=0.05$. The results were subjected to a Principal Components Analysis (PCA) and Cluster Analysis (CA) in order to observe the differences and similarities of the analyzed samples.

\section{Results and Discussion}

\subsection{Biscuit Formulation and Baking Condition Selection}

Figure 1 shows the formulated biscuits submitted to different baking conditions as well as their $\Delta \mathrm{E}$ (Table insert in Figure 1). The conditions $180^{\circ} \mathrm{C}-10 \mathrm{~min}$ and $200^{\circ} \mathrm{C}-7.5 \mathrm{~min}$ were not significantly different $(p>0.05)$, with $\Delta \mathrm{E}$ values lower than those corresponding to $200^{\circ} \mathrm{C}-10 \mathrm{~min}$. In general, the browning of the baked products increased with ahipa flour content; for example, BI of control biscuits baked at $200^{\circ} \mathrm{C}-10 \mathrm{~min}$ was $30.4 \pm 3.1$, which was significantly lower $(p<0.05)$ than the value for $250 \mathrm{AF}(\mathrm{BI}=48.3 \pm$ 2.3). This could be attributed to the Maillard reaction browning products between proteins and reducing sugars during baking. In previous works, the chemical composition of ahipa flour was characterized [11], exhibiting 57 - $90 \mathrm{~g}$ of protein $\mathrm{kg}^{-1}$ and 141 - 


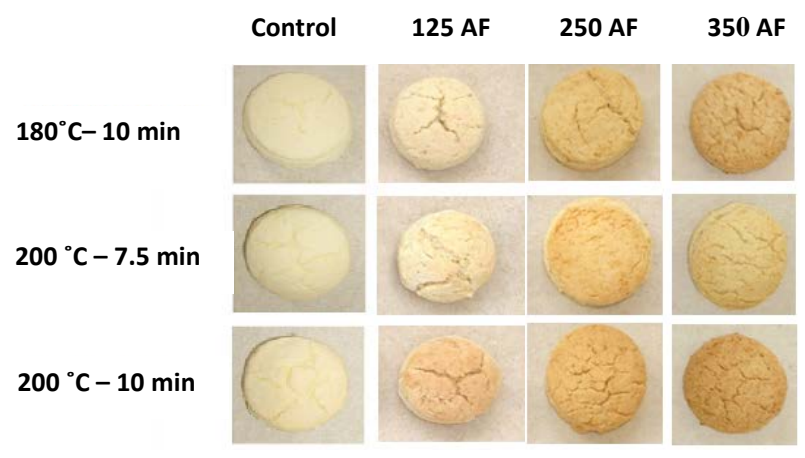

Color differences $(\Delta \mathrm{E})$ of biscuits containing ahipa flour in their formulations, submitted to different baking conditions (Control: $0 \mathrm{~g}$ ahipa flour $\mathrm{kg}^{-1}$ ).

\begin{tabular}{cccc}
\hline \multirow{2}{*}{$\begin{array}{c}\text { Ahipa flour content } \\
\text { in the formulation }\left(\mathrm{g} \cdot \mathrm{kg}^{-1}\right)\end{array}$} & $180^{\circ} \mathrm{C}-10 \mathrm{~min}$ & $200^{\circ} \mathrm{C}-7.5 \mathrm{~min}$ & $200^{\circ} \mathrm{C}-10 \mathrm{~min}$ \\
\cline { 2 - 4 } 0 & $0.00 \pm 0.00^{\mathrm{a}}$ & $0.00 \pm 0.00^{\mathrm{a}}$ & $0.00 \pm 0.00^{\mathrm{a}}$ \\
125 & $13.1 \pm 0.6^{\mathrm{b}}$ & $14.8 \pm 0.9^{\mathrm{b}}$ & $21.8 \pm 1.6^{\mathrm{b}}$ \\
250 & $13.4 \pm 0.7^{\mathrm{b}}$ & $14.8 \pm 0.9^{\mathrm{b}}$ & $21.9 \pm 1.6^{\mathrm{b}}$ \\
350 & $17.8 \pm 1.0^{\mathrm{c}}$ & $15.4 \pm 1.1^{\mathrm{b}}$ & $27.4 \pm 1.1^{\mathrm{c}}$ \\
\hline
\end{tabular}

Note: C: Control (1000 g.kg ${ }^{-1}$ corn starch); 250AF: $250 \mathrm{~g} \cdot \mathrm{kg}^{-1}$ ahipa flour $+750 \mathrm{~g} \cdot \mathrm{kg}^{-1}$ corn starch; $250 \mathrm{CF}: 250 \mathrm{~g} \cdot \mathrm{kg}^{-1}$ cassava flour $+750 \mathrm{~g} \cdot \mathrm{kg}^{-1}$ corn starch. Color differences were calculated respect to control biscuits. Reported values correspond to the mean \pm standard deviation. Data followed with the same letter within a column did not differ significantly $(p>0.05)$.

Figure 1. Photographs and mean values of color differences $(\Delta \mathrm{E})$ of biscuits containing ahipa flour in their formulations, submitted to different baking conditions.

$251 \mathrm{~g}$ of simple sugars $\mathrm{kg}^{-1}$ on dry basis [17], which support color observations (Figure 1). According to Chevallier et al. [18] cookie surface color is the result of non-enzymatic browning between reducing sugars and amino acids as well as from starch dextrinization and sugar caramelization.

Concerning texture measurements, the curves for the different biscuit formulations lacked a "defined" profile pattern in the sense that they were variable in shape and the remaining curves lost the initial penetration peak, except for the $200^{\circ} \mathrm{C}-10$ min cooking condition. McWatters et al. [19] reported that the hardness of cookies is caused by the interaction of proteins and starch by hydrogen bonding during dough development and baking. On the other hand, the texture of gluten-free biscuits is primarily attributable to starch gelatinization and super-cooled sugar rather than to a protein-starch structure development [20].

The textural parameters analyzed were the maximum force associated with the strength of the sample and the area under the curve, which represents the work done on the break (Table 1). In all tested baking conditions, 350AF biscuits presented the highest values of both parameters. Gaines et al. [21] used a puncture test on various biscuits and reported that the fracture force rose with increasing flour protein content. On the other hand, de Simas et al. [20] found a similar trend working on gluten-free cookies containing up to $300 \mathrm{~g} \cdot \mathrm{kg}^{-1}$ of king palm flour as a rich-fiber ingredient. In this sense, it is worth noting that ahipa flour supplies both protein and fiber to the biscuits formulated with corn starch.

When comparing maximum force at different baking conditions the values obtained 
Table 1. Texture parameters (maximum force and area under the curve) of biscuits containing ahipa flour in their formulations and submitted to different baking conditions.

\begin{tabular}{|c|c|c|c|c|c|c|}
\hline \multirow{3}{*}{$\begin{array}{l}\text { Ahipa flour } \\
\text { content in the } \\
\text { formulation } \\
\left(\mathrm{g} \cdot \mathrm{kg}^{-1}\right)\end{array}$} & \multicolumn{6}{|c|}{ Baking condition } \\
\hline & \multicolumn{2}{|c|}{$180^{\circ} \mathrm{C}-10 \mathrm{~min}$} & \multicolumn{2}{|c|}{$200^{\circ} \mathrm{C}-7.5 \mathrm{~min}$} & \multicolumn{2}{|c|}{$200^{\circ} \mathrm{C}-10 \mathrm{~min}$} \\
\hline & $\begin{array}{l}\text { Maximum } \\
\text { force }(\mathrm{N})\end{array}$ & $\begin{array}{l}\text { Area under } \\
\text { the curve } \\
(\mathrm{N} \mathrm{mm})\end{array}$ & $\begin{array}{l}\text { Maximum } \\
\text { force }(\mathrm{N})\end{array}$ & $\begin{array}{l}\text { Area under } \\
\text { the curve } \\
(\mathrm{N} \mathrm{mm})\end{array}$ & $\begin{array}{c}\text { Maximum } \\
\text { force }(\mathrm{N})\end{array}$ & $\begin{array}{c}\text { Area under } \\
\text { the curve } \\
(\mathrm{N} \mathrm{mm})\end{array}$ \\
\hline 0 & $6.8 \pm 0.5^{\mathrm{b}}$ & $15.6 \pm 1.1^{\mathrm{a}}$ & $3.5 \pm 0.7^{\mathrm{a}}$ & $8.8 \pm 1.3^{\mathrm{a}}$ & $7.0 \pm 1.4^{\mathrm{a}}$ & $7.5 \pm 2.8^{\mathrm{a}}$ \\
\hline 125 & $4.7 \pm 0.5^{\mathrm{a}}$ & $18.9 \pm 1.2^{\mathrm{b}}$ & $3.8 \pm 0.9^{\mathrm{a}}$ & $15.7 \pm 0.9^{\mathrm{b}}$ & $21.9 \pm 1.6^{c}$ & $31.0 \pm 2.7^{\mathrm{c}}$ \\
\hline 250 & $9.4 \pm 1.8^{c}$ & $30.6 \pm 2.5^{c}$ & $7.1 \pm 0.6^{\mathrm{b}}$ & $28.3 \pm 2.9^{c}$ & $11.6 \pm 1.6^{\mathrm{b}}$ & $19.9 \pm 1.8^{\mathrm{b}}$ \\
\hline 350 & $21.4 \pm 1.8^{\mathrm{d}}$ & $54.2 \pm 2.9^{\mathrm{d}}$ & $15.0 \pm 1.0^{c}$ & $58.7 \pm 2.6^{\mathrm{d}}$ & $22.2 \pm 1.3^{\mathrm{c}}$ & $40.0 \pm 3.6^{\mathrm{d}}$ \\
\hline
\end{tabular}

C: Control (1000 g. $\mathrm{kg}^{-1}$ corn starch); 250AF: $250 \mathrm{~g} \cdot \mathrm{kg}^{-1}$ ahipa flour $+750 \mathrm{~g} \cdot \mathrm{kg}^{-1}$ corn starch; $250 \mathrm{CF}: 250 \mathrm{~g} \cdot \mathrm{kg}^{-1}$ cassava flour $+750 \mathrm{~g} \cdot \mathrm{kg}^{-1}$ corn starch. Reported values correspond to the mean \pm standard deviation. Data followed with the same letter within a column did not differ significantly $(p>0.05)$.

for the 350AF formulation were 3.15, 3.2 and 4.3 times higher than the control for $180^{\circ} \mathrm{C}-10 \mathrm{~min}, 200^{\circ} \mathrm{C}-10 \mathrm{~min}$ and $200^{\circ} \mathrm{C}-7.5 \mathrm{~min}$, respectively. Conversely, for the 250AF formulation, maximum force was $1.38,1.65$ and 2.0 times higher than the control, for the same baking conditions respectively (Table 1 ). Thus, biscuit hardness estimated through maximum compression force was markedly higher for the highest ahipa flour substitution percentage. A comparable trend was observed for the area under the curve.

Demirkesen [22] evaluated the influence of chestnut flour at different levels on the texture of gluten-free cookies and found that the cookies prepared using exclusively chestnut flour had the highest hardness values. The author mentioned that the very high viscosity of chestnut cookie dough prevented air incorporation during the mixing and resulted in hard texture. Likewise, the high sugar content of chestnut flour could restrict the starch gelatinization and caused harder texture in the cookies.

Table 2 shows $\mathrm{a}_{\mathrm{w}}$ and moisture content for the different formulations submitted to the assayed baking conditions. Except for control biscuits baked at $200^{\circ} \mathrm{C}-7.5 \mathrm{~min}$, the remaining baking conditions showed $\mathrm{a}_{\mathrm{w}}$ values lower than 0.600 . For food products, $\mathrm{a}_{\mathrm{w}}>0.6$ could favor microbial growth and affect their stability and conservation. For all formulations, values of $\mathrm{a}_{\mathrm{w}}$ and moisture were lower in the condition of maximum temperature and time $\left(200^{\circ} \mathrm{C}-10 \mathrm{~min}\right)$, ranging in this case from 0.304 to 0.400 and 62.2 to $95.3 \mathrm{~g} \cdot \mathrm{kg}^{-1}$, respectively.

Considering that the inclusion of ahipa flour could improve the nutritional profile of the product on the basis of its higher protein and fiber content, the formulation 350AF might make the major contribution in this sense. However, textural measurements for this formulation revealed that hardness was significantly higher than the controls, added to the highest $\Delta \mathrm{E}$. Thus, the formulation $250 \mathrm{AF}$ was selected and characterized.

Owing to color and texture measurements (Figure 1 and Table 1), the baking conditions $200^{\circ} \mathrm{C}-7.5 \mathrm{~min}$ and $200^{\circ} \mathrm{C}-10 \mathrm{~min}$ were pre-selected. Then, one time-temperature combination was finally chosen from a sensory test, where the two alternatives for cooking the selected formulation (250AF) were evaluated. The attributes analyzed were color, taste, texture and overall acceptability (Figure 2). For the analysis of the results, 


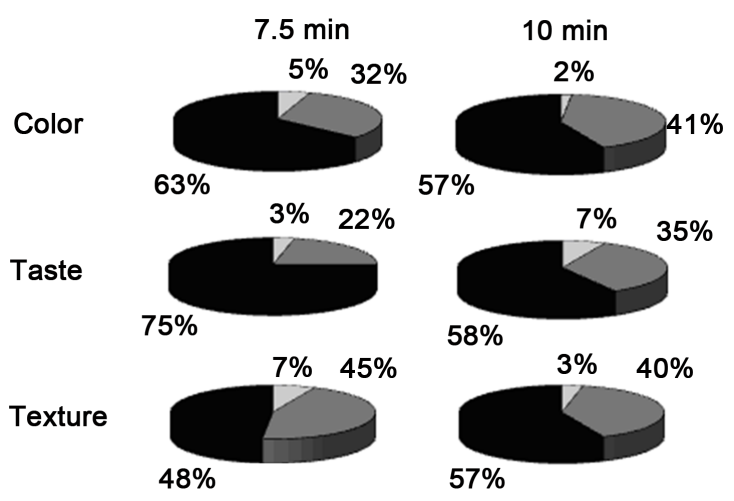

(a)
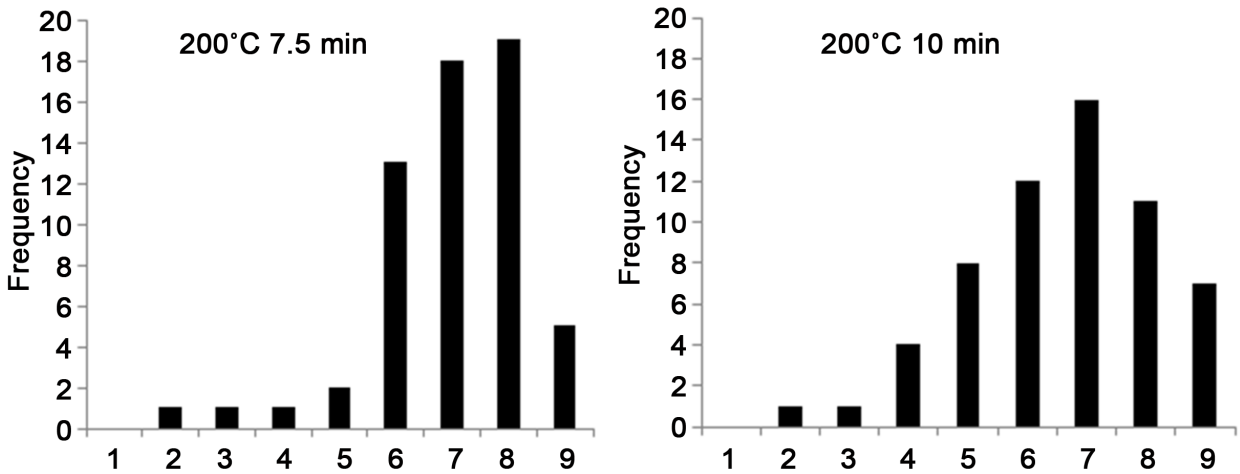

(b)

Figure 2. (a) Color, taste and texture of biscuits with $250 \mathrm{~g}$ of ahipa flour $\mathrm{kg}^{-1}$ baked at $200^{\circ} \mathrm{C}$ for 7.5 or $10 \mathrm{~min}$. Data reported are the percentage (\%) obtained for the different scores from sensory evaluation of cookies. The values of the hedonic scale were grouped into three ranges: $\square 1$ 3 (dislike), 4 - 6 (not like nor dislike) and 7 - 9 (like very much); (b) General acceptability histograms of biscuits baked at $200^{\circ} \mathrm{C}$ for 7.5 or $10 \mathrm{~min}$.

Table 2. Water activity and moisture content of biscuits containing ahipa flour in their formulations and submitted to different baking conditions.

\begin{tabular}{|c|c|c|c|c|c|c|}
\hline \multirow{3}{*}{$\begin{array}{l}\text { Ahipa flour } \\
\text { content in the } \\
\text { formulation } \\
\left(\mathrm{g} \cdot \mathrm{kg}^{-1}\right)\end{array}$} & \multicolumn{6}{|c|}{ Baking condition } \\
\hline & \multicolumn{2}{|c|}{$180^{\circ} \mathrm{C}-10 \mathrm{~min}$} & \multicolumn{2}{|c|}{$200^{\circ} \mathrm{C}-7.5 \mathrm{~min}$} & \multicolumn{2}{|c|}{$200^{\circ} \mathrm{C}-10 \mathrm{~min}$} \\
\hline & $\begin{array}{c}\text { Water } \\
\text { activity }\left(\mathrm{a}_{\mathrm{w}}\right)\end{array}$ & $\begin{array}{l}\text { Moisture } \\
\text { content } \\
\left(\mathrm{g} \cdot \mathrm{kg}^{-1}\right)\end{array}$ & $\begin{array}{c}\text { Water } \\
\text { activity }\left(\mathrm{a}_{\mathrm{w}}\right)\end{array}$ & $\begin{array}{l}\text { Moisture } \\
\text { content } \\
\left(\mathrm{g} \cdot \mathrm{kg}^{-1}\right)\end{array}$ & $\begin{array}{c}\text { Water } \\
\text { activity }\left(\mathrm{a}_{\mathrm{w}}\right)\end{array}$ & $\begin{array}{l}\text { Moisture } \\
\text { content } \\
\left(\mathrm{g} \cdot \mathrm{kg}^{-1}\right)\end{array}$ \\
\hline 0 & $0.448 \pm 0.001^{b}$ & $86.0 \pm 2.6^{\mathrm{b}}$ & $0.620 \pm 0.005^{\mathrm{d}}$ & $101.0 \pm 3.0^{\mathrm{b}}$ & $0.380 \pm 0.002^{c}$ & $73.2 \pm 4.2^{\mathrm{b}}$ \\
\hline 125 & $0.538 \pm 0.006^{c}$ & $108.6 \pm 1.5^{\mathrm{c}}$ & $0.568 \pm 0.002^{c}$ & $106.3 \pm 0.7^{\mathrm{c}}$ & $0.400 \pm 0.002^{\mathrm{d}}$ & $88.4 \pm 0.8^{c}$ \\
\hline 250 & $0.458 \pm 0.003^{\mathrm{b}}$ & $76.0 \pm 2.6^{\mathrm{a}}$ & $0.516 \pm 0.001^{b}$ & $84.0 \pm 2.9^{\mathrm{a}}$ & $0.340 \pm 0.07^{\mathrm{b}}$ & $62.2 \pm 4.5^{\mathrm{a}}$ \\
\hline 350 & $0.391 \pm 0.005^{\mathrm{a}}$ & $90.4 \pm 3.8^{\mathrm{b}}$ & $0.505 \pm 0.001^{\mathrm{a}}$ & $109.4 \pm 1.1^{\mathrm{d}}$ & $0.304 \pm 0.006^{\mathrm{a}}$ & $77.2 \pm 1.9^{\mathrm{b}}$ \\
\hline
\end{tabular}

C: Control (1000 g. $\cdot \mathrm{kg}^{-1}$ corn starch); $250 \mathrm{AF}: 250 \mathrm{~g} \cdot \mathrm{kg}^{-1}$ ahipa flour $+750 \mathrm{~g} \cdot \mathrm{kg}^{-1}$ corn starch; $250 \mathrm{CF}: 250 \mathrm{~g} \cdot \mathrm{kg}^{-1}$ cassava flour $+750 \mathrm{~g} \cdot \mathrm{kg}^{-1}$ corn starch. Reported values correspond to the mean \pm standard deviation. Data followed with the same letter within a column did not differ significantly $(p>0.05)$.

values from the hedonic scale were grouped in three ranges: 1 - 3 (dislike); 4 - 6 (not like nor dislike, i.e. indifferent); and 7 - 9 (like very much).

Figure 2(a) shows that $63 \%$ of the potential consumers gave higher score $(7-9)$ to the color of the biscuit baked at $200^{\circ} \mathrm{C}-7.5 \mathrm{~min}$, meanwhile $57 \%$ of the panelists gave 
those high punctuations to the color of the biscuit cooked for a longer time (10 min) at the same temperature. Concerning the attribute taste, $75 \%$ of the potential consumers selected the scores 7 - 9 from the hedonic scale for the condition $200^{\circ} \mathrm{C}-7.5 \mathrm{~min}$ (against the lower percentage of $58 \%$ in the case of biscuits baked at $200^{\circ} \mathrm{C}-10 \mathrm{~min}$ ). However, the texture of the product was better appreciated when biscuits were cooked for a longer time (Figure 2(a)). On the other hand, the score 8 for overall acceptability was chosen more frequently for the baking condition $200^{\circ} \mathrm{C}-7.5 \mathrm{~min}$, whereas for the condition $200^{\circ} \mathrm{C}-10 \mathrm{~min}$, the score 7 showed the highest frequency of choice (Figure 2(b)). Based on these results, the biscuits made with $250 \mathrm{~g}^{\circ} \mathrm{AF} \mathrm{kg}^{-1}$, baked at $200^{\circ} \mathrm{C}$ $7.5 \mathrm{~min}$ were chosen as the most widely accepted by the evaluation panel.

\subsection{Novel Ahipa Biscuit Formulation Compared to a Cassava Flour Equivalent Recipe}

Chemical composition of the biscuits formulated with $1000 \mathrm{~g}$ corn starch $\mathrm{kg}^{-1}$, and partially substituted $\left(250 \mathrm{~g} \cdot \mathrm{kg}^{-1}\right)$ with ahipa or cassava flour was evaluated (Table 3 ). Total ash content was higher in the cookies containing $250 \mathrm{~g} \cdot \mathrm{kg}^{-1}$ of flour (cassava or ahipa) than in the control (1000 $\mathrm{g}$ corn starch $\left.\mathrm{kg}^{-1}\right)$. This result is related to the botanical origin of the flours. Higher ash content is associated to flours obtained from tuberous roots while the contribution of corn starch to the ash level is much lower [23].

Total lipids found in the biscuits were similar and no significant differences $(p>$ 0.05 ) were observed (Table 3 ), mainly due to the high fat content (butter) included in the formulations. Besides, the content of total carbohydrates $\left(\mathrm{g} \cdot \mathrm{kg}^{-1}\right)$ showed no significant differences $(p>0.05)$ between the three analyzed formulations (Table 3 ).

Biscuits made with ahipa flour exhibited the highest protein content, due to the chemical composition of the flour [11]. Cookies containing $1000 \mathrm{~g}$ corn starch $\mathrm{kg}^{-1}$ showed the lower values $\left(13 \mathrm{~g} \cdot \mathrm{kg}^{-1}\right)$ that indicate a comparatively lower nutritional quality of this product. Cassava flour did not contribute to increase the protein content of the biscuits, thus the values were similar to those of the control formulation.

Likewise, the total dietary fiber content in AF-biscuits was the highest (50 g. $\mathrm{kg}^{-1}$ ), because ahipa flour can be considered as a fiber source [13], enhancing the nutritional profile of the developed product.

Table 3. Parameters of the texture analysis, color, water activity, moisture content, and chemical composition of biscuits containing 250 $\mathrm{g} \cdot \mathrm{kg}^{-1}$ of ahipa or cassava flour in their formulations, baked at $200^{\circ} \mathrm{C}-7.5 \mathrm{~min}$.

\begin{tabular}{|c|c|c|c|c|c|c|c|c|c|c|c|c|}
\hline \multirow[b]{2}{*}{$\begin{array}{c}\text { Biscuit } \\
\text { formulation }\end{array}$} & \multicolumn{3}{|c|}{ Texture parameters } & \multicolumn{2}{|c|}{ Color parameters } & \multirow{2}{*}{$\begin{array}{c}\text { Water } \\
\text { activity }\left(\mathrm{a}_{\mathrm{w}}\right)\end{array}$} & \multirow{2}{*}{$\begin{array}{c}\text { Moisture } \\
\text { content } \\
\left(\mathrm{g} \cdot \mathrm{kg}^{-1}\right)\end{array}$} & \multicolumn{5}{|c|}{ Chemical composition $\left(\mathrm{g} \cdot \mathrm{kg}^{-1}\right)$} \\
\hline & $\begin{array}{l}\text { Force } \\
(\mathrm{N})\end{array}$ & $\begin{array}{c}\text { Area } \\
(\mathrm{N} \mathrm{mm})\end{array}$ & $\begin{array}{l}\text { Force } \\
\text { peak } \\
\text { number }\end{array}$ & $\begin{array}{c}\text { Color } \\
\text { differences } \\
(\Delta \mathrm{E})\end{array}$ & $\begin{array}{l}\text { Browning } \\
\text { index (BI) }\end{array}$ & & & Proteins & Lipids & Ash & $\begin{array}{l}\text { Total } \\
\text { dietary } \\
\text { fiber }\end{array}$ & Carbohydrates \\
\hline $\mathrm{C}$ & $3.5 \pm 0.7^{\mathrm{a}^{*}}$ & $8.8 \pm 1.3^{\mathrm{a}^{*}}$ & $26.3 \pm 5.0^{\mathrm{b}}$ & $0.0 \pm 0.0^{\mathrm{a}^{*}}$ & $21.1 \pm 1.5^{\mathrm{a}}$ & $0.620 \pm 0.005^{c^{*}}$ & $101 \pm 3^{\mathrm{b}^{*}}$ & $13 \pm 1^{\mathrm{a}}$ & $172 \pm 10^{\mathrm{a}}$ & $6.7 \pm 0.4^{\mathrm{a}}$ & $19 \pm 8^{\mathrm{a}}$ & $810 \pm 20^{\mathrm{a}}$ \\
\hline $250 \mathrm{AF}$ & $7.1 \pm 0.6^{\mathrm{b}^{*}}$ & $28.3 \pm 2.9^{b^{*}}$ & $12.8 \pm 3.9^{\mathrm{a}}$ & $14.8 \pm 0.9^{c^{*}}$ & $36.2 \pm 2.2^{c}$ & $0.516 \pm 0.001^{\mathrm{a}^{*}}$ & $84 \pm 3^{a^{*}}$ & $26 \pm 1^{\mathrm{b}}$ & $172 \pm 5^{a}$ & $8.4 \pm 0.2^{\mathrm{b}}$ & $50 \pm 14^{\mathrm{b}}$ & $793 \pm 8^{a}$ \\
\hline $250 \mathrm{CF}$ & $7.2 \pm 0.6^{\mathrm{b}}$ & $27.1 \pm 2.3^{\mathrm{b}}$ & $12.8 \pm 3.6^{\mathrm{a}}$ & $12.0 \pm 0.8^{\mathrm{b}}$ & $30.7 \pm 0.7^{\mathrm{b}}$ & $0.547 \pm 0.002^{\mathrm{b}}$ & $85.3 \pm 0.5^{\mathrm{a}}$ & $15.7 \pm 0.1^{\mathrm{a}}$ & $182 \pm 5^{\mathrm{a}}$ & $7.7 \pm 0.1^{b}$ & $32 \pm 1^{\mathrm{a}}$ & $795 \pm 7^{\mathrm{a}}$ \\
\hline
\end{tabular}

C: Control (1000 g.kg-1 corn starch); 250AF: $250 \mathrm{~g} \cdot \mathrm{kg}^{-1}$ ahipa flour $+750 \mathrm{~g} \cdot \mathrm{kg}^{-1}$ corn starch; $250 \mathrm{CF}: 250 \mathrm{~g} \cdot \mathrm{kg}^{-1}$ cassava flour $+750 \mathrm{~g} \cdot \mathrm{kg}^{-1}$ corn starch. ${ }^{\star}$ From Table 1 , Table 2 and Figure 1. Color differences were calculated respect to control biscuits. Reported values correspond to the means \pm standard deviations. Different letters in the same column indicate significant differences $(p<0.05)$. 
Concerning biscuit texture, the maximum force registered for the 250AF biscuits was higher (1.4 - 2.0 times) than the control. Formulations including ahipa or cassava flour showed the same texture behavior, with regard to maximum force, area under the curve and crunchiness (Table 3), taking into account that peaks in biting test represent fracture events, where an association between the number of peaks and the perception of crunchiness has been mentioned [24]. Thus, ahipa and cassava biscuit formulation showed similar performance in terms of texture, being the maximum force and energy required to bite twice and three times higher than the control, respectively.

Regarding color measurements, partially substituted formulations differed significantly from the control. Although statistically significant $(p<0.05)$, slight differences between cassava and ahipa flour formulation were found in terms of total color difference $(\Delta \mathrm{E})$ and browning index (BI) (Table 3$)$. It is worth noting that the value used to determine whether the $\Delta \mathrm{E}$ was visually obvious was $\Delta \mathrm{E}>3$, which denotes color differences noticeable to the human eye [25]. Particularly, color differences could be attributed to the chemical composition of ahipa flour, mainly to protein and fiber content. These darker tints have been explained by a greater number of reducing ends involved in a Maillard reaction [26].

Both moisture content and $\mathrm{a}_{\mathrm{w}}$ were higher for control biscuits (Table 3). Moreover, $\mathrm{a}_{\mathrm{w}}$ value for control formulation indicated that this product could have compromised its microbial stability during storage. Aparicio-Sanguilán et al. [27] reported increased moisture and $\mathrm{a}_{\mathrm{w}}$ for biscuits enriched with a resistant starch-containing product extracted from bananas; the increase was related to a relative abundance of amorphous starch zones, which had a considerable influence on water absorption.

Complementing chemical and physical analysis, results from the sensory tests performed in order to evaluate the acceptability of the developed product (250AF) in comparison to the control biscuits and the same percentage of substitution with cassava flour (250CF) are shown in Figure 3. The average scores for taste, color, texture and overall acceptability are presented in the Table insert in Figure 3. In this case, $75 \%$ of the panelists rated with scores $>7$ the 250AF biscuits in terms of color, preferring them to the control (Figure 3(a)). Thus, the change in color was deemed acceptable for consumers.

For the attribute taste, the most accepted formulation was the one made with $1000 \mathrm{~g}$ of corn starch kg-1 (Figure 3(a)). Conversely, when evaluating the attribute texture, the biscuits that had higher acceptance were those made with cassava flour. Possibly, the panelists recognized control biscuits as "more familiar" in terms of taste, since it represents a product more frequently consumed even by non-celiac people. Texture of the control formulation was comparatively less appreciated, being associated by consumers to a "gritty" or less cohesive product. Thus, the association between crunchiness and force peak number does not seem so clear or evident in this case, according to texture and sensory results comparison.

Overall acceptability of the biscuits in the sensory panel was evaluated as good, given that the predominant score was 7 for this attribute (Figure 3(b)). This fact would be favorable for a potential market introduction, since the achieved general acceptance could be similar to biscuits formulated exclusively with corn starch, which are usually available in shops and shelves of products suitable for celiac patients. 


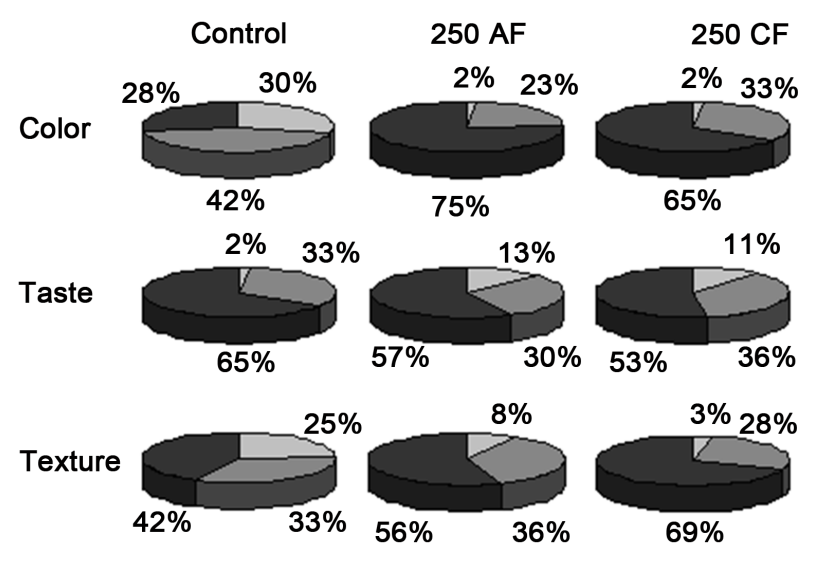

(a)
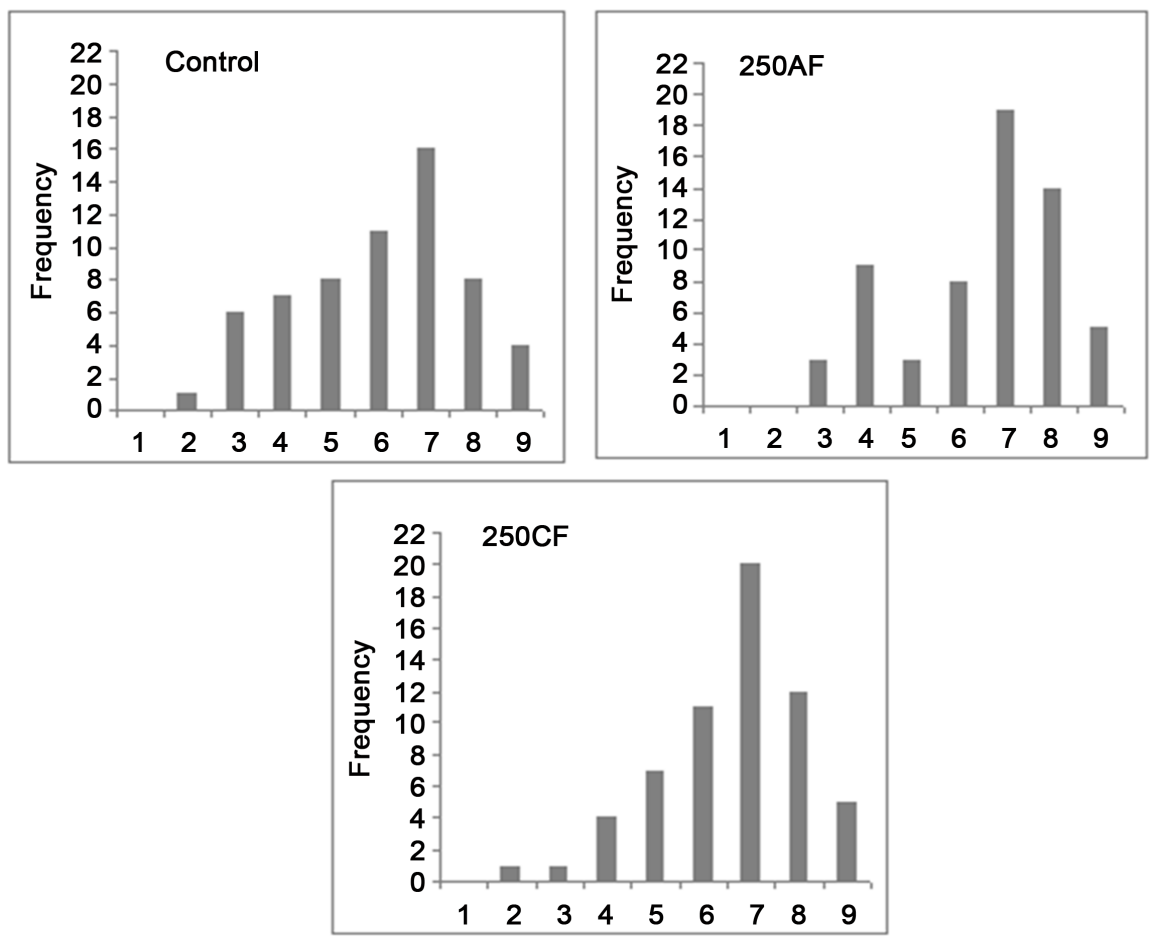

(b)

Sensorial attributes of biscuits containing $250 \mathrm{~g}$ of ahipa or cassava flour $\mathrm{kg}^{-1}$ in their formulations, baked at $200^{\circ} \mathrm{C}-7.5 \mathrm{~min}$

\begin{tabular}{ccccc}
\hline Biscuit formulation & Color & Taste & Texture & Overall acceptability \\
\hline Control & $5.03 \pm 2.00^{\mathrm{a}}$ & $6.95 \pm 1.44^{\mathrm{a}}$ & $5.64 \pm 2.09^{\mathrm{a}}$ & $6.00 \pm 1.78^{\mathrm{a}}$ \\
$250 \mathrm{AF}$ & $7.26 \pm 1.26^{\mathrm{a}}$ & $6.28 \pm 2.05^{\mathrm{a}}$ & $6.51 \pm 1.79^{\mathrm{a}}$ & $6.52 \pm 1.68^{\mathrm{a}}$ \\
$250 \mathrm{CF}$ & $7.05 \pm 1.41^{\mathrm{a}}$ & $6.23 \pm 1.82^{\mathrm{a}}$ & $6.82 \pm 1.51^{\mathrm{a}}$ & $6.61 \pm 1.52^{\mathrm{a}}$
\end{tabular}

C: Control (1000 g. $\mathrm{kg}^{-1}$ corn starch); 250AF: $250 \mathrm{~g} \cdot \mathrm{kg}^{-1}$ ahipa flour $+750 \mathrm{~g} \cdot \mathrm{kg}^{-1}$ corn starch; $250 \mathrm{CF}: 250 \mathrm{~g} \cdot \mathrm{kg}^{-1}$ cassava flour $+750 \mathrm{~g} \cdot \mathrm{kg}^{-1}$ corn starch. Reported values correspond to the means \pm standard deviations. Different letters in the same column indicate significant differences $(p<0.05)$.

Figure 3. (a) Color, taste and texture of biscuits with $100 \%$ corn starch (control), $250 \mathrm{~g}$ of ahipa flour $\mathrm{kg}^{-1}(250 \mathrm{AF})$ and $250 \mathrm{~g}$ of cassava flour $\mathrm{kg}^{-1}(250 \mathrm{CF})$ baked at $200^{\circ} \mathrm{C}$ for 7.5 or $10 \mathrm{~min}$. Data reported are the percentage (\%) obtained for the different scores from sensory evaluation of cookies. The values of the hedonic scale used were grouped into three ranges: $\square 1-3$ (dislike), $\square 4$ 6 (not like nor dislike) and 7 - 9 (like very much); (b) General acceptability histograms of biscuits baked at $200^{\circ} \mathrm{C}$ for 7.5 or $10 \mathrm{~min}$. 


\subsection{Principal Component and Cluster Analysis}

The results of quality attributes, chemical composition, and sensory characteristics were subjected to multivariate analysis by Principal Component Analysis (PCA) and Cluster Analysis (CA). In these analyses, the following variables: protein and fiber content, browning index, water activity, force, overall acceptability and sensorial attributes (color, texture and taste), which allowed to discriminate the samples, were considered.

There were two main components that explained the total variance (Figure 4(a)). These main components were associated to the addition of nutritionally differentiated root flours (PC1) and the type of nutritionally differentiated flour (PC2), which explained the $89.0 \%$ and $11.0 \%$, respectively. PC1 was strongly related to all the analyzed variables, meanwhile PC2 was essentially defined by the sensorial and chemical variables: protein content $(0.62)$, fiber $(0.43)$, texture $(-0.42)$, overall acceptability $(-0.31)$ and taste (0.23).

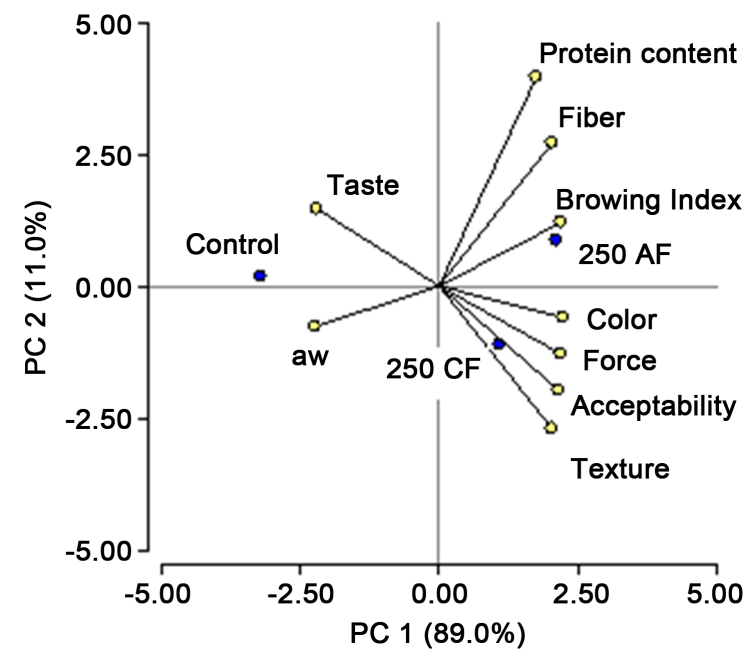

(a)

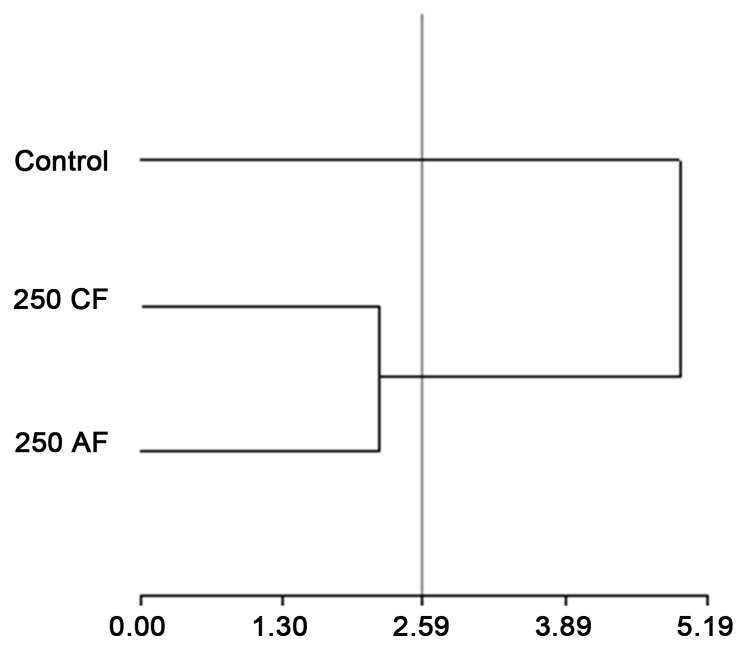

(b)

Figure 4. (a) Principal component analysis (PCA) and (b) cluster analysis of quality attributes, chemical composition and sensory characteristics of biscuits containing nutritionally differentiated root flours (cassava or ahipa). 
Cluster Analysis was performed, using the uncorrelated variables that represent data obtained in the principal component analysis. Figure 4(b) shows the dendrogram obtained. Samples were gathered into two distinct groups near to the Euclidean distance of 2.59. One of them corresponded to the control sample, which is clearly different from the others. The observation that biscuits formulated with $250 \mathrm{~g} \cdot \mathrm{kg}^{-1}$ of nutritionally differentiated root flours (cassava or ahipa) were similar between them was also made by the panelists. In the overall analysis of the sensory characteristics, panelists were not able to discriminate between them, assigning scores to both samples that were not statistically different in the global appreciation. It should be noted that when samples belonged to the same group for a high Euclidean distance, there was a significant similarity between them in statistical terms, based on the variables tested. However, the overall perception of the panelists did not quite corroborate these findings based on the overall acceptability scores (Figure 3 ).

\section{Conclusions}

The formulation containing $250 \mathrm{~g}$ of $\mathrm{AF} \mathrm{kg}^{-1}$ was selected in order to improve the nutritional profile of the product on the basis of its higher protein $\left(26 \mathrm{~g} \cdot \mathrm{kg}^{-1}\right)$ and fiber (50 $\mathrm{g} \cdot \mathrm{kg}^{-1}$ ) content. It is worth noting that gluten-free products derived exclusively from cassava flour have relatively low protein and fiber levels.

Sensory tests ultimately defined baking condition, being $200^{\circ} \mathrm{C}-7.5 \mathrm{~min}$ chosen as the most widely accepted by the evaluation panel. This time-temperature combination represents also an advantage from the operative point of view, since it allows to an energy and cooking time saving.

Comparing the novel ahipa biscuit formulation to a cassava flour equivalent recipe (a common ingredient for gluten-free products elaboration), its performance was similar in terms of textural characteristics (maximum force, energy required to bite and force peak number). However, slight variations were observed in color total differences and browning index. Likewise, the overall acceptability of the biscuits formulated with AF and CF exhibited better sensory general acceptability than the control, since the predominant score was 7 for this attribute.

Principal components analysis allowed to relate quality attributes, chemical composition and sensory characteristics of biscuits containing cassava or ahipa flours. Cluster analysis indicated that biscuits formulated with $250 \mathrm{~g} \cdot \mathrm{kg}^{-1}$ of nutritionally differentiated root flours (cassava or ahipa) were similar between them and this statistical inference has also been mirrored by the panelists.

New interest in under-utilized crops and their derived products (i.e. flours, starches, protein concentrates and isolates) arises largely from the finding and endorsement of nutritionally significant attributes. These products can also increase their value as functional foods and ingredients. On the basis of the results from the present work, ahipa flour could partially substitute corn starch in future formulations for the production of gluten-free foodstuffs, allowing getting nutritionally balanced products and good consumer acceptance.

\section{Acknowledgements}

Financial support provided by the ANPCyT (PICT 2011-1213) and CONICET (PIP 
0555) is gratefully acknowledged. Authors wish to thank to Fassola Hugo, Rohatsch Pablo and Feltan Rafael, from the EEA Montecarlo (INTA, Misiones), for ahipa and cassava root provision.

\section{References}

[1] Kaur, M., Sandhu, K.S., Arora, A. and Sharma, A. (2014) Gluten Free Biscuits Prepared from Buckwheat Flour by Incorporation of Various Gums: Physicochemical and Sensory Properties. LWT-Food Science and Technology, 62, 628-632. https://doi.org/10.1016/j.lwt.2014.02.039

[2] Winger, M., Khouryieh, H., Aramouni, F. and Herald, T. (2014) Sorghum Flour Characterization and Evaluation in Gluten-Free Flour Tortilla. Journal of Food Quality, 37, 95-106. https://doi.org/10.1111/jfq.12080

[3] Rosell, C.M. and Matos, M.E. (2015) Market and Nutrition Issues of Gluten-Free Foodstuff. In: Arranz, E., Fernández-Bañares, F., Rosell, C.M., Rodrigo, L. and Peña, A.S., Eds., Advances in the Understanding of Gluten Related Pathology and the Evolution of Gluten-Free Foods, Omnia Science, Barcelona, 675-713. https://doi.org/10.3926/oms.268

[4] De La Barca, A.M.C., Rojas-Martínez, M.E., Islas-Rubio, A.R. and Cabrera-Chávez, F. (2010) Gluten-Free Breads and Cookies of Raw and Popped Amaranth Flours with Attractive Technological and Nutritional Qualities. Plant Foods for Human Nutrition, 65, 241246. https://doi.org/10.1007/s11130-010-0187-z

[5] Majzoobi, M., Vosooghi Poor, Z., Jamalian, J. and Farahnaky, A. (2016) Improvement of the Quality of Gluten-Free Sponge Cake Using Different Levels and Particle Sizes of Carrot Pomace Powder. International Journal of Food Science \& Technology, 51, 1369-1377. https://doi.org/10.1111/ijfs.13104

[6] Sciarini, L.S., Pérez, G.T., De Lamballerie, M., León, A.E. and Ribotta, P.D. (2012) Partial-Baking Process on Gluten-Free Bread: Impact of Hydrocolloid Addition. Food and Bioprocess Technology, 5, 1724-1732. https://doi.org/10.1007/s11947-011-0529-3

[7] Rybicka, I., Krawczyk, M., Stanisz, E. and Gliszczyńska-Świgło, A. (2015) Selenium in Gluten-Free Products. Plant Foods for Human Nutrition, 70, 128-134. https://doi.org/10.1007/s11130-015-0467-8

[8] Okpala, L.C. and Okoli, E.C. (2013) Optimization of Composite Flour Biscuits by Mixture Response Surface Methodology. Food Science and Technology International, 19, 343-350. https://doi.org/10.1177/1082013212452587

[9] Mussury, R.M., Scalon, S.P.Q., Silva, M.A., Silva, T.F., Gomes, H. and Gassi, R. (2013) Postharvest Conservation of the Tuberous Roots of Pachyrhizus ahipa (Wedd) Parodi. Anais da Academia Brasileira de Ciências, 85, 761-768. https://doi.org/10.1590/S0001-37652013005000035

[10] Leonel, M., Bortolucci Ferrari, T., Sarmento, S.B.S. and Alvares de Oliveira, M. (2005) Planting Time, Developmental Stages and Characteristics of Roots and Starch of Pachyrhizus ahipa. Scientia Agricola (Piracicaba, Brazil), 62, 528-533. https://doi.org/10.1590/S0103-90162005000600003

[11] Doporto, M.C., Mugridge, A., García, M.A. and Viña, S.Z. (2011) Pachyrhizus ahipa (Wedd.) Parodi Roots and Flour: Biochemical and Functional Characteristics. Food Chemistry, 126, 1670-1678. https://doi.org/10.1016/j.foodchem.2010.12.053

[12] Doporto, M.C., Dini, C., Mugridge, A., Viña, S.Z. and García, M.A. (2012) Physicochemical, Thermal and Sorption Properties of Nutritionally Differentiated Flours and Starches. Journal of Food Engineering, 113, 569-576. https://doi.org/10.1016/j.jfoodeng.2012.07.021

[13] Doporto, M.C., Viña, S.Z. and García, M.A. (2012) Obtención y caracterización de harina a partir de raíces de Pachyrhizus ahipa. In: López, O.V., García, M.A. and Viña, S.Z., Eds., 
Pachyrhizus Ahipa: Revalorización de un cultivo ancestral, Editorial Académica Española, Madrid, 115-146.

[14] Olivera, D.F. and Salvadori, V.O. (2012) Kinetic Modeling of Quality Changes of Chilled Ready to Serve Lasagna. Journal of Food Engineering, 110, 487-492. https://doi.org/10.1016/j.jfoodeng.2011.12.015

[15] Buera, M.P., Petriella, C. and Lozano, R.D. (1985) Definition of Colour in the Non-Enzymatic Browning. Die Farbe, 33, 316-326.

[16] Association of Official Analytical Chemists (AOAC) (1990) Official Methods of Analytical of the Association of Official Analytical Chemists, 15th Edition, Association of Official Analytical Chemists, Washington DC.

[17] Dini, C., Doporto, M.C., García, M.A. and Viña, S.Z. (2013) Nutritional Profile and Anti-Nutrient Analyses of Pachyrhizus ahipa Roots from Different Accessions. Food Research International, 54, 255-261. https://doi.org/10.1016/j.foodres.2013.07.027

[18] Chevallier, S., Colonna, P., Buléon, A. and Della Valle, G. (2000) Physicochemical Behaviors of Sugars, Lipids, and Gluten in Short Dough and Biscuit. Journal of Agricultural and Food Chemistry, 48, 1322-1326. https://doi.org/10.1021/jf990435+

[19] McWatters, K.H., Ouedraogo, J.B., Resurrection, A.V.A., Hung, Y.C. and Philips, R.D. (2003) Physical and Sensory Characteristics of Sugar Cookies Containing Mixtures of Wheat, Fonio (Digitaria exilis) and Cowpea (Vigna unguiculata) Flours. International Journal of Food Science \& Technology, 38, 403-410. https://doi.org/10.1046/j.1365-2621.2003.00716.x

[20] de Simas, K.N., Vieira, L.N., Podestá, R., Müller, C.M.O., Vieira, M.A., Beber, R.C., Reis, M.S., Barreto, P.L.M., Amante, E.R. and Amboni, R.D.M.C. (2009) Effect of King Palm (Archontophoenix alexandrae) Flour Incorporation on Physicochemical and Textural Characteristics of Gluten-Free Cookies. International Journal of Food Science \& Technology, 44, 531-538. https://doi.org/10.1111/j.1365-2621.2008.01840.x

[21] Gaines, C.S., Kassuba, A. and Finney, P.L. (1996) Using Wire-Cut and Sugar-Snap Formula Cookie Test Baking Methods to Evaluate Distinctive Soft Wheat Flour Sets: Implication for Quality Testing. Cereal Foods World, 41, 155-160.

[22] Demirkesen, I. (2016) Formulation of Chestnut Cookies and Their Rheological and Quality Characteristics. Journal of Food Quality, 39, 264-273. https://doi.org/10.1111/jfq.12209

[23] Suárez Moreno, D.X. (2003) Guía de procesos para la elaboración de harinas, almidones, hojuelas deshidratadas, y compotas. Serie Ciencia y Tecnología No. 113, Convenio Andrés Bello, Bogotá.

[24] Laguna, L., Varela, P., Salvador, A., Sanz, T. and Fiszman, S.M. (2012) Balancing Texture and Other Sensory Features in Reduced Fat Short-Dough Biscuits. Journal of Texture Studies, 43, 235-245. https://doi.org/10.1111/j.1745-4603.2011.00333.x

[25] Francis, F.J. and Clydesdale, F.M. (1975) Food Colorimetry: Theory and Applications. AVI Publishing Co., Westport.

[26] Peressini, D. and Sensidoni, A. (2009) Effect of Soluble Dietary Fibre Addition on Rheological and Breadmaking Properties of Wheat Doughs. Journal of Cereal Science, 49, 190-201. https://doi.org/10.1016/j.jcs.2008.09.007

[27] Aparicio-Saguilán, A., Sáyago-Ayerdi, S.G., Vargas-Torres, A., Tovar, J., Ascencio-Otero, T.E. and Bello-Pérez, L.A. (2007) Slowly Digestible Cookies Prepared from Resistant StarchRich Lintnerized Banana Starch. Journal of Food Composition and Analysis, 20, 175-181. https://doi.org/10.1016/j.jfca.2006.07.005 
Submit or recommend next manuscript to SCIRP and we will provide best service for you:

Accepting pre-submission inquiries through Email, Facebook, LinkedIn, Twitter, etc. A wide selection of journals (inclusive of 9 subjects, more than 200 journals) Providing 24-hour high-quality service

User-friendly online submission system

Fair and swift peer-review system

Efficient typesetting and proofreading procedure

Display of the result of downloads and visits, as well as the number of cited articles Maximum dissemination of your research work

Submit your manuscript at: http://papersubmission.scirp.org/

Or contact fns@scirp.org 